\title{
教師の防火教育に対する意識と防火対応能力 RESEARCH ON TEACHERS' IDEA OF FIRE PREVENTION EDUCATION AND TEACHERS' ABILITY TO PREVENT FIRE
}

\author{
建 部 謙 治*, 吉岡 竜已** \\ Kenii TATEBE and Tatsumi YOSHIOKA
}

\begin{abstract}
The purpose of this study is to research on teachers' idea of fire prevention education and teachers' ability to prevent fire. We have two things that we want to find out about teachers. One is a questionnaire survey about their idea of fire prevention education and their ability to prevent fire. The other is an experiment with evacuation simulator involving their preference on evacuation route in fire disaster.

The results are summarized as follows;

- Almost all of the teachers have not received fire prevention education when they were university students.

- Almost all of the teachers admit that they need to general fire prevention education.

- Only about 22 percent of teachers have confidence in their ability of fire prevention education.

- Teachers do not always have knowledge of fire disasters.

- Teachers do not always choose safe route at fire disaster in evacuation simulator study.
\end{abstract}

Keywords: elementary school, fire, teacher, antidisaster, education, idea 小学校,火災,教師,防災,教育,意識

1. はじめに

\section{1 研究背景}

小学校は災害弱者である児童が多数生活を行う場所であり、防災 対策については特に注意を要する。そのような場所において児童に 対し普段では防火教育を指導し、災害時には避難誘導を行う教師の 防火に対する意識・知識・行動を知ることは大きな意味をもつもの である。なぜならば、学校において災害が発生した場合に児童を唯 一保護出来るのは教職員であり、その能力が児童の生死を左右寸る 場合もありうるからである。また災害時の避難誘導は安全な経路選 択に重要な役割を果たすことが既報 1)で確認されている。さらに防 火教育については一般教養や各学習科目の中でなされ教師が関わる 内容、時間を考えれば、その影響が大きいことはいうまでもない。 既往研究 1 5) では保護する対象である児童に対する防災対策の充実 のため、児童の避難経路選択傾向や空間認知、火災に対寸る意識・ 知識や火災時の行動特性を分析してきた。しかし、防災対策をさら に万全にするためには教育や保護を行う教師自身の防火教育に対す る意識や、防火に対応する能力を知る必要がある。

\section{2 既往研究}

児童の避難行動を対象とした研究としては、本研究の基䃈となる
ものとして筆者らによる経路マップ法を用いた児童単独の避難行動 特性の調查、学校空間認知や火災知識・行動判断による経路選択傾 向への影響を分析したもの 2 4)がある。また、本研究で使用する避難 シミュレータの開発とそれを利用して火災避難時を想定した児童の 行動研究としては著者らによるもの 1,5 がある。

一方、学校教育における防㷋教育への学習指導要領の影響は大き いと考えられるが、学習指導要領の変遷過程から防災教育への展開 を論じたものには城下らの研究がある 6)。それは現行の系統主義を 基礎とした単元構成は防災教育には不利であるとし、大学での教職 課程における「総合演習」などの活用や、国民の高い防災意識の保 持が重要である事を説いている。指導を行う教師に対して防火・防災 教育に対する意識を国際的に調査したものには柴田ら 7)によるもの がある。ブラジルと台湾におけるアンケート調查によって、両国で は防火・防災に対して意識が高くなく、避難訓練を含む防火教育の 必要性を程度の差があれ認識していること、防火教育を行う適龄期 については教師の年齢や教育経験により差があること等を明らかに している。しかし、日本国内において教師を対象にした防災に対す る意識や能力を明らかにした研究はほとんど行われていない。

\footnotetext{
* 愛知工業大学工学部都市環境学科 教授・博士 (工学)

** 愛知工業大学工学部 非常勤講師・博士 (工学)
}

Prof., Dept. of Urban Environment, Faculty of Engineering, Aichi Institute of Technology, Dr. Eng.

Part-time Lecturer, Faculty of Engineering, Aichi Institute of Technology, Dr. Eng. 


\section{3 研究目的}

本研究は、児童の安全にとって重要な役割を果たす教師の防火教 育に対する重要性の認識や評価、適齢期などの考え方を把握すると ともに、教師自身の防火に対寸る能力について、火災知識や避難経 路選択傾向より明らかにすることを目的とする。

\section{4 研究方法}

教師自身の火災等の災害に対する意識・知識や、火災時に取りう る行動を調查するため、教師を対象にして以下の 2 つの実験調查を 行う。

(1)アンケート調査

調查対象者の性別 - 年代 - 最終学歴 - 勤務経験等の被験者の属 性や、火災に対しての意識、知識、火災時に取りうる行動、ま た防火教育に対する考え方の調査を行う。

(2)避難シミュレータ実験

時間制限を加えた避難シミュレータ実験によって、教師の火災時 の経路選択傾向を探る。また、避難シミュレータの防災教育への 利用に関するアンケートを行う主1)。

避難シミュレータ実験は、時間制限の要素を加え被験者を焦らせ 臨場感を増したものである。この実験に使用寸る避難シミュレータ は、図 1 のようなパソコン上画面に動画で構成されており、下方の パネルのボタンをマウスでクリックすることにより仮想空間内にお いて前進や方向転換等の通路の移動が出来、その移動感を動画で表 現している。避難シミュレータと実験手法の詳細については既報 1 、 5)を参照されたい。

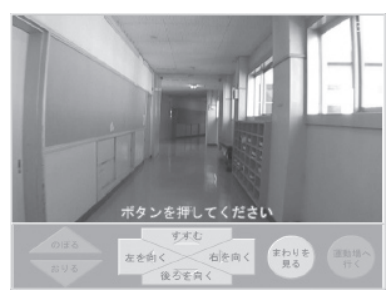

図 1 避難シミュレータ画面

\section{5 調査方法}

調査対象は豊田市内の小学校 4 校と中学校 3 校、名古屋市内の小 学校 2 校の教師 239 人である(表 1 )。豊田市内の小中学校教師に対し ては前項(1)のンケート調查のみを行い、名古屋市内の小学校教師 に対しては(1)のアンケート調査と、(2)の避難シミュレータ実験を行 った。

表 1 調査概要

\begin{tabular}{|c|c|c|c|c|}
\hline & 学校名 & $\begin{array}{c}\text { 調査対象教師 } \\
\text { (人) }\end{array}$ & $\begin{array}{l}\text { 調 } \\
\text { 査 }\end{array}$ & 調查実施時期 \\
\hline \multirow{7}{*}{$\begin{array}{l}\text { 豊 } \\
\text { 市 }\end{array}$} & OB 小学校 & 33 & \multirow{7}{*}{ (1) } & \multirow{3}{*}{2003 年 12 月 } \\
\hline & T 小学校 & 38 & & \\
\hline & NHM 小学校 & 17 & & \\
\hline & HHM 小学校 & 19 & & \multirow{4}{*}{2004 月 1月 } \\
\hline & AHG 中学校 & 36 & & \\
\hline & HM 中学校 & 28 & & \\
\hline & MT 中学校 & 40 & & \\
\hline \multicolumn{2}{|c|}{ 豊田市教師合計 } & 211 & \multirow{3}{*}{$\begin{array}{l}\text { (1) } \\
\text { 及 } \\
\text { び } \\
\text { (2) }\end{array}$} & \multirow{3}{*}{$\begin{array}{r}2005 \text { 年 } 10 \text { 月 } \\
\sim 12 \text { 月 }\end{array}$} \\
\hline \multirow{2}{*}{$\begin{array}{l}\text { 名 } \\
\text { 克 } \\
\text { 至 }\end{array}$} & NY 小学校 & 13 & & \\
\hline & $\mathrm{NI}$ 小学校 & 15 & & \\
\hline \multicolumn{2}{|c|}{ 名古屋市教師合計 } & 28 & & \\
\hline \multicolumn{2}{|c|}{ 教師合計 } & 239 & & \\
\hline
\end{tabular}

※(1)アンケート調査（2)シミュレータ実験
豊田市内の小中学校についてはアンケート用紙を配布して後日回 収をする方法をとる。名古屋市内の小学校ではコンピュータ室でア ンケート用紙を配布し、避難シミュレータ実験後に回収を行った。

\section{2. 教師の属性と防火教育意識}

\section{1 教師の属性と防災教育研修の有無}

被験者の属性と防災能力に関する背景を知るため、年齢、教育経 験、防㷋教育研修経験注 2)の有無等を調查する。

被験者の年齢構成は図 2 のように 40 代の教師がもつとも多く、教 師の年齢構成は、40 代、30 代、50 代、20 代の順になっている。

被験者の教育経験年数については図 3 のように 10 年以上の経験を 持つ教師が最も多い。

そして被験者の最終学歴については図 4 のように、大半が大学を 卒業して教師となっている。よって調查対象の教師が防災教育研修 を受ける機会は、大学の学部在籍時と教師となってからの研修等で ある。その大学等での防災教育研修の有無については図 5 のように、 大半の教師が大学等では防災教育研修は受けていないと答えている。

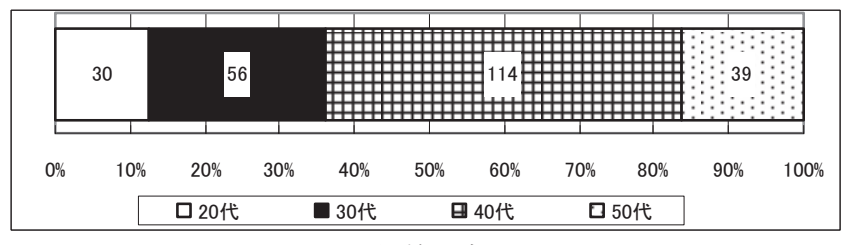

図 2 年齢構成

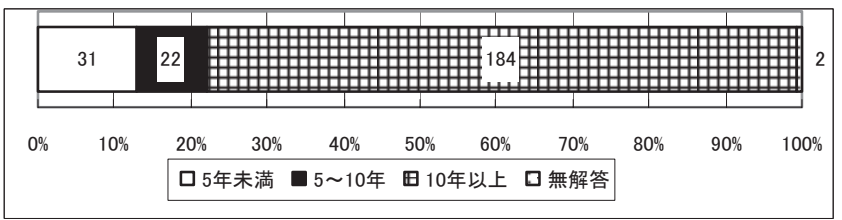

図 3 教育経験年数

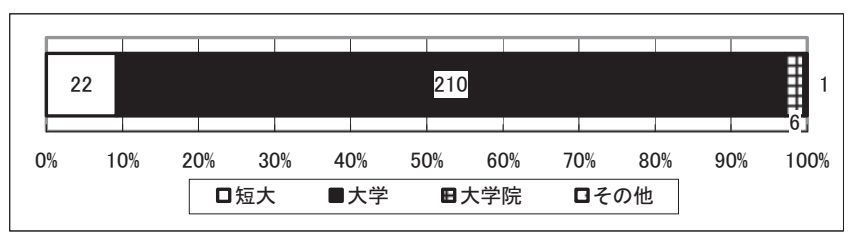

図 4 最終学歴

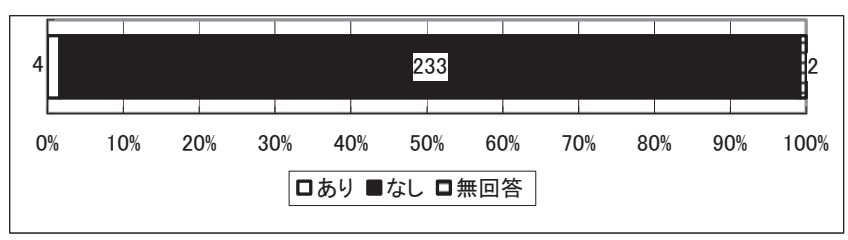

図 5 大学等での防災教育研修の有無

以上より本報で対象にした教師は、40 代の教師がもつとも多く、 10 年以上の教育経験を持ち、最終学歴は大学卒が多く、また大学等 では防災教育研修は受けていない。

言い換えるならば大学等では、防災教育を受ける制度が十分整っ 
ていないことが明らかになった。

\section{2 防火教育に対する教師の意識}

文献 9 と文献 10 によれば小学校においては、年 3 回は地震や地 震火災についての避難訓練や学級指導の「特別活動」の時間に安全 指導が行われている。そのような現状を踏まえ、教師の避難訓練と 避難訓練以外の防火教育に対寸る評価、防火教育の適齢期、防火教 育の最重要項目、防火教育を実施すべき機関、防火教育への自信等 についての意識を調査する。

\section{2 .1 避難訓練とそれ以外の防火教育に対する評価}

校舎から脱出する避難訓練の評価は図 6 のとおりである。

大半の教師が避難訓練は必要であると答えており、防火教育にお ける避難訓練の必要性が広く認識されていることがわかる。

さらに、避難訓練が必要であると答えた教師に現状への評価を聞 いたところ、図 7 のように、「現状で十分である」と考えているもの が「もっと充実させるべきである」と答えているものより多い。こ れは前述のように年 3 回は地震や地震火苂の避難訓練が行われてい ることから、訓練回数等については現状での避難訓練に満足してい るもの考えられる一方で、授業時間等の問題で時間をこれ以上取ら れたくないと考えている側面もある。また、もつと充実させるべき であると考えている教師は約 3 割強いる。これは避難訓練が教師、 児童双方に事前に告知されているものが多く、教師の管理下で行わ れている状況の批判として、避難訓練の内容の充実等質的な改善の 要望とも考えられる。

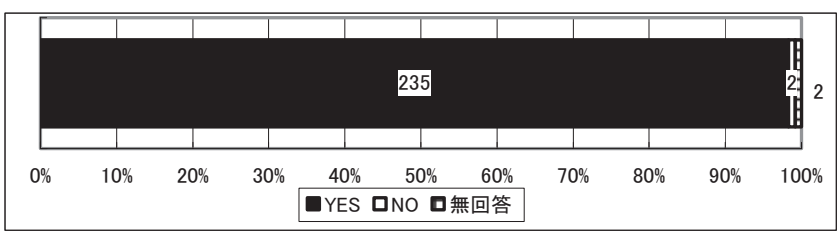

図 6 避難訓練の必要性について

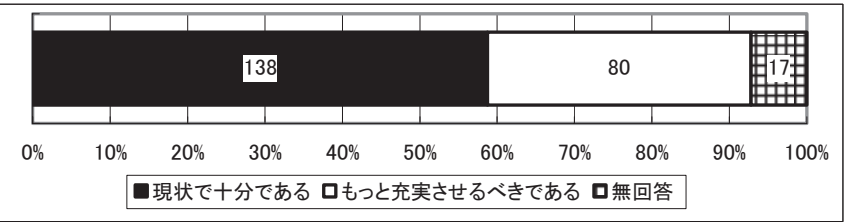

図 7 避難訓練を必要と答えた教師の現状への評価

表 2 避難訓練を必要と答えた教師の現状への評価（年代別）

\begin{tabular}{|l|r|r|c|}
\hline & 現状で十分である & もっと充実させるべきである & $5 \%$ 有意差 \\
\hline 20 代 & $46 \%$ & $54 \%$ & あり \\
\hline その他 & $66 \%$ & $34 \%$ & क \\
\hline
\end{tabular}

表 3 避難訓練を必要と答えた教師の現状への評価（男女別）

\begin{tabular}{|l|r|r|c|}
\hline & 現状で十分である & もっと充実させるべきである & $5 \%$ 有意差 \\
\hline 男 & $69 \%$ & $31 \%$ & なし \\
\hline 女 & $58 \%$ & $42 \%$ & . \\
\hline
\end{tabular}

さらに、現状の避難訓練への評価がどの年代で変わるかをみるた めに、年齢別の分析を行った。若い教師ほど避難訓練を充実させる べきと考えている割合が多いが、10 年代毎の年代毎では有意差はな かった。しかし、表 2 に示すように 20 代の若い教師はその他の年代
と比較すると $5 \%$ の危険率で有意差があり、避難訓練をもつと充実さ せるべきと考える傾向が強いことが明らかになった。

また、男女による違いについては表 3 のように $5 \%$ 危険率で有意差 がなく、性別による意識の違いはなかった。

よって教師全体として現状の避難訓練には満足している者が多い 傾向が明らかになった。しかし、これから中核を担っていく20代の 若い教師は避難訓練が十分ではないと考えるものが他の年代より高 い傾向があることも明らかになった。それは回数だけではなく、質 的な改善の要望もあるものと考えられる。

また、避難訓練以外の防火教育の必要性を聞いたところ結果は、 図 8 のようになった。避難訓練以外の防火教育についても大半の教 師が必要であると考えている。避難訓練のみではなく防火に対して 多角的に教育寸る必要があると考えている教師が多い。

文献 9 において学級活動での災害安全指導時間数が調査されてい るが、そこでは大半の学校が $1 \sim 3$ 校時行っているという現状であ った。それに対する評価は図 9 のようになった。

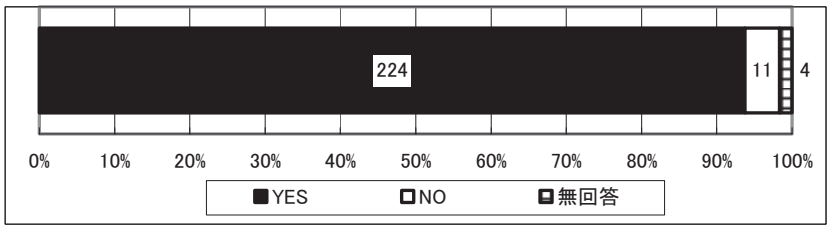

図 8 防火教育（避難訓練以外）の必要性

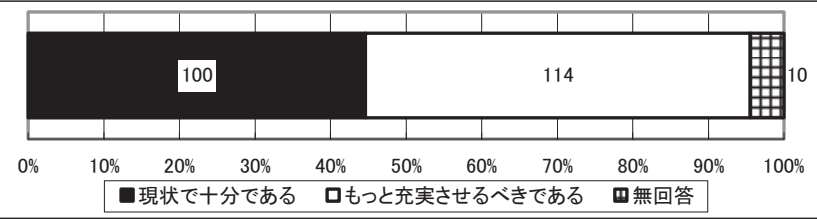

図 9 防火教育（避難訓練以外）が必要と答えた教師の現状評価

避難訓練以外の防火教育が必要であると答えた教師のなかでは 「現状で十分である」と答えた教師より、「もっと充実させるべきで ある」と答えた教師の方が多かった。しかし図 7 の避難訓練に対す る評価と比べると、避難訓練以外の防火教育についてはもっと充実 させるべきであるというものが、 $5 \%$ の危険率で有意な差を持って多 い。なお、自由記述による意見では、「シミュレーションによる地震 体験」や「災害の恐ろしさの映像視聴」というものが提案されてい る。

以上より、避難訓練、またそれ以外の教育についての必要性を教 師は認めており、避難訓練とそれ以外の防火教育に対しては、避難 訓練以外の防火教育の充実に対してより要望が大きいことが明らか になった。

\subsection{2 教師の考える防火教育の適齢期}

児童の成長過程を考えれば、どの時期に防火教育を行うのが適 切であるかを知る事は重要である。教師の考える防火教育の適齢 期について、豊田市内の小中学校教師 211 人は、図 10 のように 5 歳以上 10 歳未満が適齢期であると考える教師が約 6 割弱、次 いで 10 歳以上 15 歳未満が適齢期と考える教師が約 3 割 5 分で ある注3) 


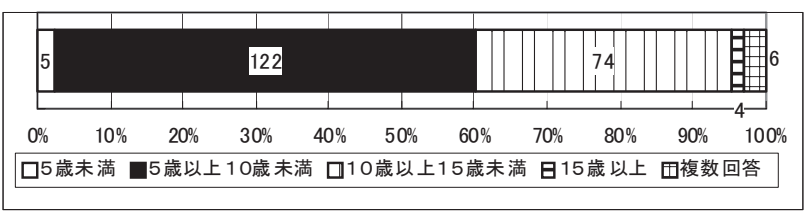

図 10 豊田市の教師の考える防火教育の適齢期

また、名古屋市内の小学校教師 28 名は、図 11 のように、回答者 のほぼ全員が小学生に対して行うべきであると考えている。これら 2 つの調查結果より教師は、年齢別の設問では 5 歳から 15 歳の小学 校低学年から中学生の時期を、学校種別での設問では小学校に在籍 する時期が防災教育を行う適齢期とする傾向がある。さらに経路マ ップ法による調査 $2^{2} 4$ )によると、安全な避難経路の選択が出来るか どうかの変化があらわれる時期が小学 4 年生の段階である。

以上の調查結果と既往研究とあわせて考えれば、特に小学校の時 期が防火教育にとって重要な時期であるといえる。このことから小 学校低学年から学齢に応じた防火教育を行っていく必要がある。

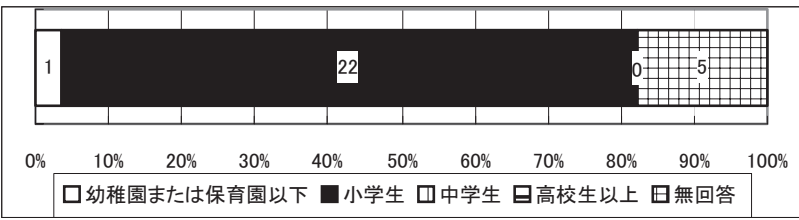

図 11 名古屋市の教師の考える防火教育の適齢期

\subsection{3教師の考える防火教育の重要項目}

教師の考える防火教育の重要項目について 2 つ選択をする形式で 回答を求めた。その結果を順位別に示したものが図 12 である。

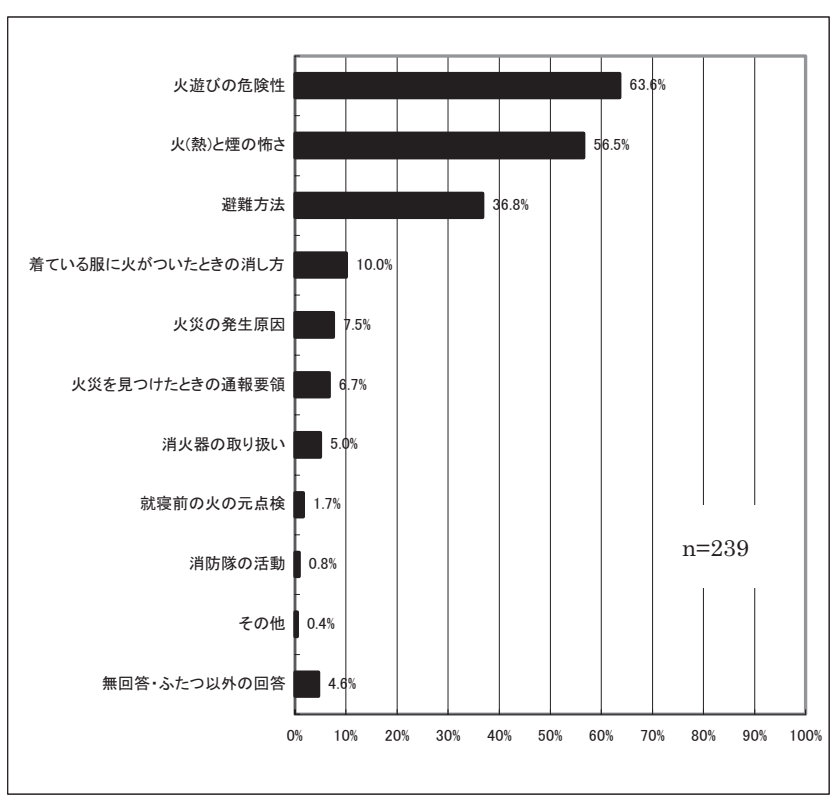

図 12 防火教育重要項目 $(1$ 人 2 回答)

これらをグルーピングすると表 4 のように、「火災の危険性」、「火 災時の対処」、「火災予防」、「その他」の 4 つに大別できる。すなわ ち、「火の危険性」、次いで「火災時の対処」に該当する項目を重要
視していることがわかる。このことより教師は防火教育において、 まず、火災そのものに対する警戒心を持つことと、その対処法に重 点を置く傾向がある。

表 4 防火教育重要項目の分類

\begin{tabular}{|c|c|}
\hline 分類 & 項目 \\
\hline \multirow{2}{*}{ 火災の危険性 } & ・ 火遊びの危険性 \\
\hline & - 火(熱)と煙の怖さ \\
\hline \multirow{4}{*}{ 火災時の対処 } & ・炎災を見つけたときの通報要領 \\
\hline & - 避難方法 \\
\hline & ·着ている服に火がついたときの消し方 \\
\hline & ·消火器の取り扱い \\
\hline \multirow{2}{*}{ 火災予防 } & ·就寝前の火の元点検 \\
\hline & · 火災の発生原因 \\
\hline \multirow{2}{*}{ その他 } & ·消防隊の活動 \\
\hline & ·その他 \\
\hline
\end{tabular}

\section{2 .4 教師の考える防火教育を行うべき機関}

図 13 は教師にどの機関が防火教育を行うべきかを質問したもの である。

子供の両親がもっとも多く、次に学校、地域、消防機関と続いて いるが、それぞれの間には $5 \%$ 危険率で有意差はみられず、特定の 機関が防火教育を行うべきとは考えていない。

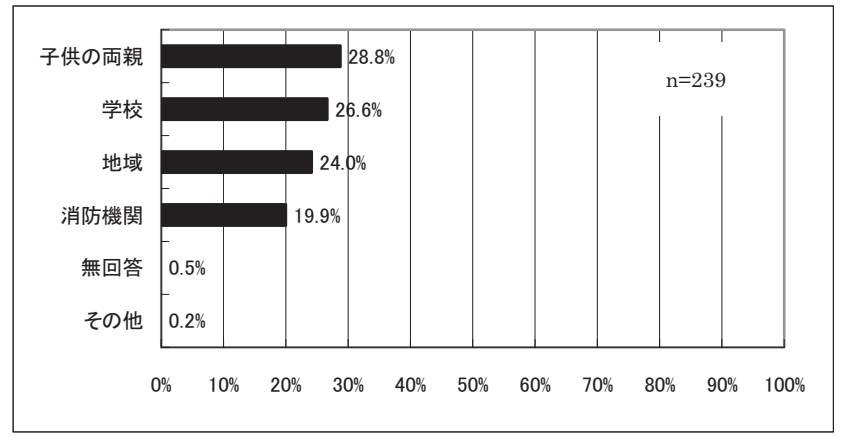

図 13 防火教育を実施すべき機関(複数回答可)

\section{2 .5 教師の防火教育に対する自信}

図 14 は教師に防火教育への自信について質問したものである。

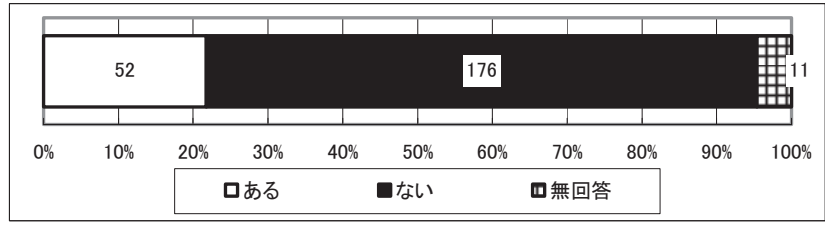

図 14 防火教育への自信

7 割以上の教師が防火教育に対して自信を持っていない。その理 由としては知識・経験不足をあげるものは約 3 割と最も多く、また

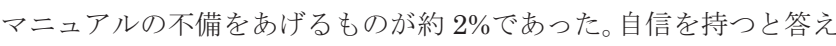
た理由として、約 3 割弱は指導経験があるからと答えており最も多 い回答となった。その他では「阪神淡路大震災の教訓から学んだこ とがある」、「ビデオ等の教材の活用や災害に対しての科学的知識を 持っている」等があるが約半数は無回答であった。

2.1 において大学生時代に防災教育研修を受けていないものが多 かった。また、教師となってからの防災教育に関する研修について 
もほとんどの教師が受けていない。本報で対象とした教師は地方公 務員であり、地方公務員法により研修が義務付けられている「教職 員等中央研修」での「危機管理」や学校安全指導者養成研修がある が、校務主任等、特定の人に限られているのが現状である。このた め一般の教師の防火教育を行う自信には結びついていない。

\section{3. 教師の防火教育能力}

前章において教師は自分の防火教育の能力に自信を持っていない 者が 7 割以上を占めることが明らかになった。その理由としては、 その災害の経験と知識の無さが挙げられている。そこで別の視点か ら教師の防火能力を把握するため名古屋市内の小学校教師 28 人に 対し、火災知識、避難シミュレータによる避難行動についての実験 調查を行った。

\section{1 火災知識}

火災知識については、煙の有毒性、可視性、熱性、速度、流動性、 また避難時に空を閉めて逃げる理由について質問をする。窓を閉め る理由と流動性以外は 2 択の選択式で、流動性については 4 肢の選 択式、空を閉める理由は自由記述式とする。

図 15 は、その正解率を示したものである。煙の速度については全 員正解だったが、可視性、熱性については 9 割を下回った。特に建 物火災初期の煙の流動性については 7 割程度であり、また、避難す るときに空を閉める理由については正解率が 4 割を切っていて、教 師といえども火災知識が十分ではないことが確認された。

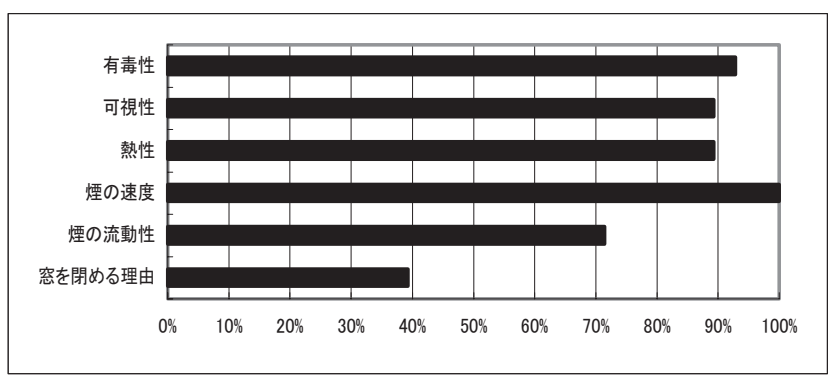

図 15 教師の煙の知識の正解率

教師には消火器や防火扉等の防災設備の使用経験についても必ずし も全員があるわけでないこと ${ }^{10}$ かからも、教師自身の防火能力につい ては十分ではない実態が明らかになった。

このことからも教師に対しても火災の知識についての体系的な教 育が必要であると考えられる。

\section{2 火災時の避難行動}

火災時の避難行動については、避難シミュレータを用いて安全 な避難経路を選択出来たかどうかをみるための指標「回避率注 4)」 を軸に分析をする。経路選択の詳細については文献 1〜 5 を参照 されたい。調査対象と、想定火災室、避難開始位置は次の表 5、 表 6 のとおりである。また対象学校の平面図はそれぞれ図 16 、 図 17 のとおりである。

表 $5 \mathrm{NY}$ 小学校避難シミュレータ実験内容一覧

\begin{tabular}{|c|c|c|c|}
\hline 調查日 & 想定火災室 & 避難開始位置 & 被験者数 \\
\hline 1日目 & 1階大土間 & 6 年 1 組 & 9 人 \\
\hline 2日目 & 1階大土間 & 4 年 1 組 & 4 人 \\
\hline
\end{tabular}

表 6 NI 小学校避難シミュレータ実験内容一覧

\begin{tabular}{|c|c|c|}
\hline 想定火災室 & 避難開始位置 & 被験者数 \\
\hline もも組、ホール 1 & 4 年 2 組 & 15 人 \\
\hline \multicolumn{2}{|c|}{} \\
\hline \multicolumn{2}{|c|}{}
\end{tabular}

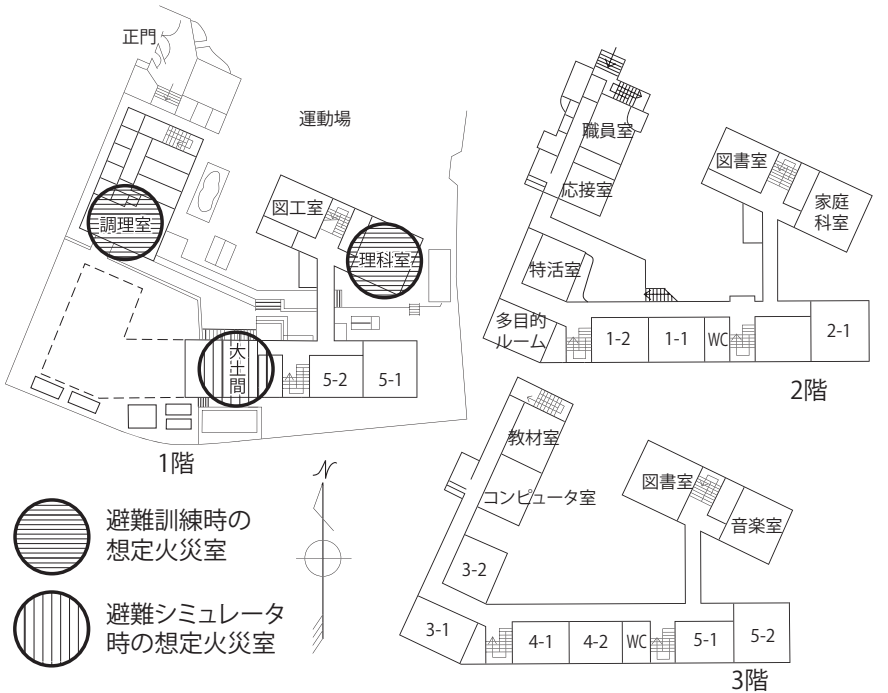

図 $16 \mathrm{NY}$ 小学校平面図

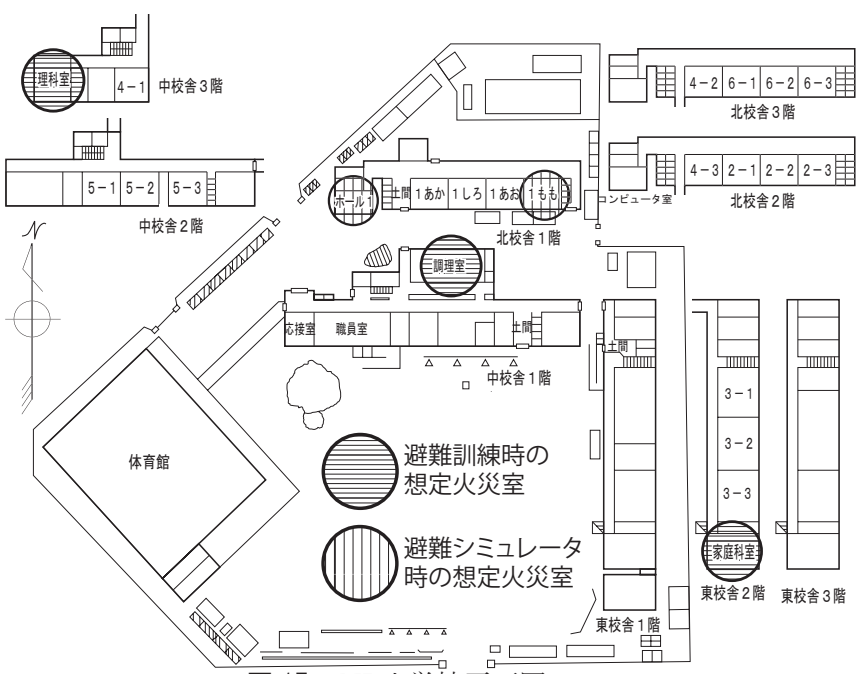

図 17 NI 小学校平面図

$\mathrm{NY}$ 小学校での教師の回避率は図 18 のように 1 日目は $100 \% 、 2$ 日目は $25 \%$ である。1 日目と 2 日目では表 5 のように避難開始位置 が違うため別々に集計している。

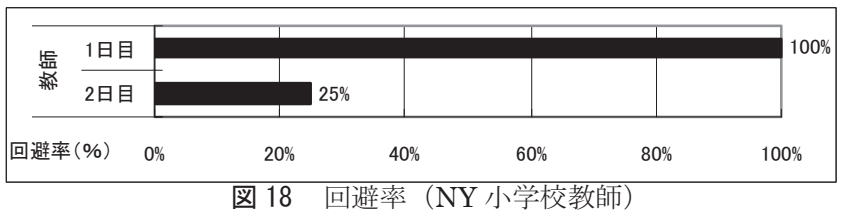

また、NI 小学校では回避率は図 19 のように $93 \%$ ある。

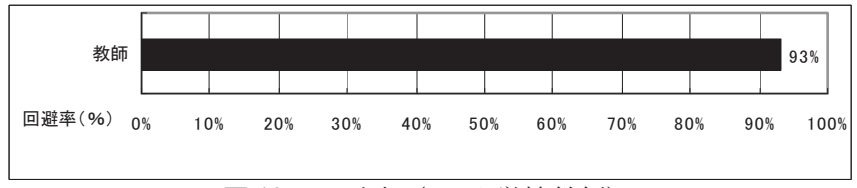

図 19 回避率（NI 小学校教師） 
教師の避難シミュレータによる回避率を児童のもの11.12) と比較す ると、NY 小学校 1 日目と NI 小学校の教師では教師の方が当然高い 結果となった。しかし、NY 小学校における避難開始室を変え難易 度を高めた 2 日目の結果をみると、図 19 に示すように回避率が $25 \%$ と著しく下がり、教師でも設定条件によっては避難出来ないことが あることが明らかになった。また NY 小学校において 1 日目の回避 率が高い理由のひとつとして、設定された正しい避難経路が避難開 始室から職員室へ向かうものだったこともあげられる。そして NI 小学校でも全員が避難出来たわけではない。避難においては予期せ ぬ場所からの出火等の場合に正しい避難経路が選択出来るのかどう かが問われる。現状の避難は教師の引率の下に児童が避難すること が前提となっているため、重大な問題と言わざるをえない。

\section{4. まとめ}

本章では、アンケート調査により、防火教育に対する考え方、火 災知識、さらに避難シミュレータによる避難経路選択傾向の実験調 查を行い、以下の事を明らかにした。

教師に対寸る防火教育について

・教師のほとんどが大学時代及び教師になっても防火教育を受けて いない。

教師の防火教育に対する意識について

・これから中核を担っていく若い教師は避難訓練が十分ではないと 考えるものが他の年代より高い傾向がある。

・避難訓練とそれ以外の防火教育については必要性があるとする教 師が 9 割以上と多い。

・避難訓練以外の防火教育の充実を望む教師が半数以上と多い。

・防火教育は小学校低学年から段階的に行っていく必要がある。

・防火教育では火や煙の危険性について優先して教えるべきと考え る教師が 6 割以上と多い。

・特定の機関が防火教育を行うべきと考えている傾向はみられない。 ・防火教育を行う自信を持つ教師は 2 割程度と少ない。自信を持た ない教師の 3 割弱は自身の経験不足を理由に挙げている。

教師の災害対応能力について

・特に避難時の空の閉鎖理由についての知識は 4 割以下と低い正答 率であった。

・教師であっても火災について十分な知識を持っているわけではな く体系的な教育が必要である。

・教師であっても火災の状況によっては安全に避難出来ない可能性 がある。

以上のことより、教師に対する防災教育が十分になされていない 現状では、教師の防火教育や避難時における能力に問題がある場合 があり、児童に対する防火教育や避難誘導にも問題が生ずる可能性 があることが明らかになった。

今後は児童に対寸る防火教育の評価とともに、教師の防火教育に 対する能力を高める体制づくりが求められる。

\section{謝辞}

各小学校・中学校では調査にあたり、教職員の皆様に多大なご協力を 賜りました。ここに深謝の意を表します。
注

1）本報では避難シミュレータが本題ではないので避難シミュレー タの利用に関するアンケートは取り扱わない。

2）文献 8 によると、防災教育は地震、火災、風水害など幅広い災 害を対象としている。一方、県や市の教育委員会が実施する防 災教育研修はその対象者が校務主任や教頭など管理職にあたる 教員が代表して受けに行き、これらの成果が学校で実施する避 難訓練等に反映される。このため一般の教師の大半は防火教育 であれ、地震防災教育であれ、いずれも本格的な研修は受けて いない。また今回のアンケート調査は防火を中心に行っている。 このため、「防災」教育研修の有無を、「防火」教育を受けてい ないと読みかえて論文を構成している。

3） アンケート設問の選択肢については名古屋市内の小学校教師に 対しては学校種によって、豊田市内の小中学校教師に対しては 年齢によって作成している。

4）「回避率」とは、(「回避者数」／「被験者数」）×100（\%）で 表されるものである。「回避した」、「回避していない」という判 定については想定火災室に近い階段室とその周辺が煙に污染さ れるものと仮定し、そこに進入した被験者は安全に避難が出来 なかったと判定した。なお、シミュレータ内では、煙の描写は 直上階の階段室周辺に行い、1 階を火災階とした場合の 3 階の 描写については煙の上昇性に対する被験者の判断を探るために あえて煙の描写はしていない。

\section{参考文献}

1）吉岡竜巳、建部謙治、鈴木賢一：火災避難時のストレスと避難誘導が児童 の危険回避行動に与える影響について 避難シミュレータを用いた火炎避難 実験、日本建築学会計画系論文集 No.615、pp.69〜 74、2007.5

2)建部謙治、鈴木賢一、小森圭一：単独避難の経路選択傾向、火災時におけ る学校の避難計画に関する基礎的研究 その 1、日本建築学会計画系論文集、 No.515、pp.159〜164、1999.1

3)鈴木賢一、建部謙治：児童の学校空間認知と避難経路選択、学校における児 童の火災避難行動に関する基礎的研究 その 2、日本建築学会計画系論文集、 No.522、pp.201 206、1999.8

4)建部謙治、鈴木賢一：火㷋知識・行動判断の避難経路選択一の影響、学校に おける児童の火災避難行動に関する基礎的研究 その 3 、日本建築学会計画 系論文集 No.556、pp.177〜182、2002.6

5)吉岡竜巳、建部 謙治：火災時における児童の避難行動に関する研究 避難 シミュレータの開発と有効性について、日本建築学会計画系論文集 No.579、pp.39〜44、2004.5

6)城下英行、川田惠昭：学習指導要領の変遷に見る防災教育展開の課題、自然 災害科学、Vol.26, No.2、pp. 163 176、2007.8

7）柴田靖史、建部謙治：防火・防災教育に関寸る先生の意識調査、日本火災 学会誌火災 vol.54 No.2、pp.27〜32、2004.4

8）文部省体育局監修：教職員のための防災事典、日本体育・学校健康センタ 一、pp.34〜36、1999.3

9）戸田芳雄：学校における防災教育の現状と文部科学省の施策、中等教育資 料 vol.54 No.9 pp.10〜13、ぎょうせい、2005.9

10）小森圭一：小学校の防災計画に関寸る基礎的研究-火災時における览童 の避難経路選択と要因分析、1996 年度愛知工業大学大学院建設システム工 学研究科修士論文 1997.3

11) 吉岡竜巳、建部謙治、鈴木賢一：避難シミュレータを利用した小学校にお ける防苂教育の研究、日本建築学会大会学術講演梗概集 E-1 分冊 pp. 911 912、2006. 9

12)吉岡竜巳：小学校におけるシミュレータを用いた避難行動分析と防火教 育に関する研究、愛知工業大学博士論文、2007. 12 